\title{
COSERIAN PERIPATETICS BOOK REVIEW: EUGENIU COȘERIU - VOCAȚIA UNIVERSALITĂȚII \\ Edited and coordinated by Gheorghe Popa Știința Publishing House, Chișinău
}

\author{
Diana CHIBAC \\ „Yuriy Fedkovych” Chernivtsi National University, Ukraine
}

ANCA URSACHE TCACIUC

„Nicolae Titulescu” University of Bucharest, Romania

\begin{abstract}
Eugenio Coșeriu's Monumental Centenary Event - 100 years since his birth, is successufully celebrated both in the space of his native lands and abroad. A series of scientific and cultural events are organized. In this context, Stitința Publishing House launches the Eugeniu Coșeriu - Vocația universalității / Vocation of Universality book collection under the coordination of Gheorghe Popa. The book covers the protagonist'life in thematic section: in the field of linguistics, literature, interviews - dialogues with and about Eugenio Coseriu, evocations - confessions and reconstructions, reflections on the great coserian model, and, of course, at the end, the iconographic compartment that makes accessible the life in images of master Coseriu.
\end{abstract}

Keywords: Eugenio Coseriu, centenary, linguist, scientist, universality, bookreview.

\section{Eugenio Coșeriu's Monumental Centenary Event - 100 years since his birth}

On the $100^{\text {th }}$ anniversary occasion of the remarkable Eugenio Coseriu's birth, on July $27^{\text {th }}, 2021$, both in the space of his native lands and abroad, a series of cultural and scientific events are scheduled throughout this year. As an international linguist, a prominent representative of the diaspora, he had an exemplary scientific career and a special destiny. As a perfect polyglot, Eugenio Coseriu demonstrated an overview of languages and the language as a people symbolic activity, imposing himself in the field of linguistics first in his indisputable capacity as a scientist who found the solution of Ferdinand de Saussure's dichotomies language - speech and synchrony - diachrony, through his early studies Sistema norma y abla, (1952), Sincronia e dicronia 
e istoria, (1958), and later as a language theorist. According to his exegetes, he fundamentally reconstructed the science of language known in the ' $60 \mathrm{~s}$, in the heyday of structuralism as a pilot discipline of the humanities, establishing it as an authentic science of culture, coherent and systematic, integrative and polyphonic. As Mircea Borcila pointed out, through its breadth and depth, coserian theory provides the foundation and the legitimate epistemological status of human linguistics. In this context of Coseriu's scientific contribution, several educational institutions are involved in organizing events on the centenary occasion.

Thus, the International Congress Coseriu's Linguistics. Origin and Actuality, organized by the University of Zurich, between June 16th-18th, through its representative, the Head of the Department of Romanic Linguistics Johanes Kabatek, one of the largest promoters of coserian linguistic and his collaborators, addressed a broad topic, aiming to create a space for debate on the origin and evolution of Coseriu's thinking; the organizers invited participants to discuss the influence of the coserian conception in the linguistics of the twentieth century and its continued presence in the twenty-first century, as well as its relationship with other current linguistic theories and currents.

Plenary lectures, round tables and section papers brought together participants - academics, researchers, PhD students - from Germany, USA, Mexico, Japan, Slovenia, Croatia, Brazil, France, Uruguay, Chile, Spain, Italy, Romania, Switzerland, who have developed in their communications these ideas and applied the methodological instruments of integral linguistics to the interpretation of language facts, thus demonstrating the theoretical and applicative potential of Coseriu's conception.

During the congress, severalvolumes on the themewerelaunched:Eugenio Coseriu, Wolf Dietrich, Geschichte der ramanischen Sprachwissenchaft, Band 2: Von Nebrija (1942) bis Celso Cittadini (1601): Die Epoche des Humanismus. Tübingen, Narr 2020; Eugeniu Coșeriu, Vocația universalității (editor Gheorghe Popa), Editura Știința, Chișinău, 2021; Eugenio Coseriu, Past, Present and Future (editori: Klaas Willems, Cristinel Munteanu), De Gruyter, Berlin, 2021; Dincolo de structuralism. Scrisori către Eugeniu Coșeriu și istoria lingvisticii în secolul al XX-lea. Corespondența Marius Sala - Eugeniu Coșeriu, J. Kabatek și Cristina Bleorţu, Editura Academiei Române, București, 2021; Irina-Marinela Deftu, J. Kabatek, Eugenio Coseriu - Beyound Structuralism, De Gruyter, Berlin, 2021, ș. a.

The Zurich Congress will remain in history files for its impeccable organization, diversity and large number of participants (over 300) and also for J. Kabatek's welcome initiative to interview coserian linguists from several countries and making them available to all interested, on the web page of the Coseriu 100 congress - the 70 interviews conducted so far.

After the large-scale manifestation in Zurich, on July, $27^{\text {th }}$ this year, several events took place simultaneously. Thus, the online scientific session 
Eugenio Coseriu - 100 years since his birth, initiated by the Romanian Academy - Iasi branch, highlighted the scientific side of the homage, among the speakers being present those who knew him personally: Mircea Borcila, Stelian Dumistrăcel, Nicolae Saramandu.

The commemoration of the $100^{\text {th }}$ birth anniversary of Eugeniu Coseriu, organized online by the Babes -Bolyai University of Cluj and the Eugeniu Coseriu Cultural-Scientific Association had as guests some of the most important coserian disciples, who listened to his courses and did $\mathrm{PhD}$ under his guidance: Johanes Kabatek - Switzerland, Manuel Casrdo Velarde Spain, Oscar Loureda Lamas - Germany, Magdalena Viramonte - Argentina, Adolfo Elizaincin - Uruguay, Alfredo Matus - Chile, Cleminton Pinheiro Brazil, Floarea Verban - Italy. They paid homage to the personality of the celebrant, pointing to her demanding and rigorous appearance, but also to the Coseriu Humankind, so generous with a lively sense of humor. Of course, other participants who had the honor to meet the remarkable Eugenio Coseriu evoked his contribution in terms of knowing the Romanian language in the Occident and its intransigence when it comes to Moldovianism and the socalled „Moldovian” language: Ludmila Zbant - University of State from Chisinau, Ileana Oancea - West University of Timisoara, Sanda Ardeleanu - University of Suceava, Maria Slehtitchi - University of Balti. The young soprano of Bessarabian origin, Isabelle Haile from London, also took part in Cluj commemoration by interpreting fragments of sacred music, who perfumed the event with a special lyricism.

Continuing in this note, between September 24 and 26, will take place at the State University of Moldova, Chisinau, The International Colloquium on Language Sciences Eugenio Coseriu, 16th edition, with the theme Language, Creativity, Culture - resistance structures of human being, in collaboration with Stefan cel Mare University of Suceava, Romania and Yuriy Fedkovych Chernivtsi National University, Ukraine, and, on October 7, The International Scientific Conference - Modern Philology will also take place in Chisinau and Balti, Republic of Moldova: achievements and perspectives in the european context, 15th edition; Eugeniu Coșeriu: 100 years since birth - Language as a sum of values.

\section{Team building: Știința Publishing House, Gheorghe Popa and his book collaborators}

With a history of more than half a century, Stiința Publishing House is the oldest publishing institution in the Republic of Moldova, founded in 1959 within the Academy of Sciences in order to value the scientific research results of local scholars. In nowadays, with an indisputable notoriety in collaboration with the most prestigious publishing houses abroad, Știința Publishing House conforms to the demands of the time under its unmistakable mark of quality and style, bringing to the fore 
famous names of scientists, professors and specialists in different fields of activity, both national and international space.

One of the ambitious projects in which the publishing house is involved, entitled Notorious Personalities Collection has been a considerable success over the years among readers, proof that it has already reached number 12 of the series by publishing in Romanian, in the spring of this year, the volume Eugenio Coseriu - The vocation of universality, under the impeccable coordination of the linguist Gheorghe Popa, rector of the Alecu Russo State University from Balti.

In the note edition of this book, the famous professor Gheorghe Popa remembers Maestro Coseriu who considered that „there is no (...) a better way to honor a researcher than to dedicate him a contribution in a field of research to which himself devoted a good part of his labor power to it". (Eugeniu Coșeriu, Limba română în fața Occidentului. Cluj-Napoca, Dacia Publishing House, 1994, p. 11). By virtue of these sayings, an entire team is involved in the wonderful project of the centenary Coseriu, „which comes not only to complete the book collection Notorious personalities of the prestigious Stiința Publishing House, but also to revive the older collaborations with E. Coseriu, who published him his first book in Romanian Lingvistică din perspectivă spațială și antropologică, (1994), co-organazing and co-financing at the same time, Colloquium Philology of the 21st Century, 1st edition, (2001).

At the same publishing house appeared, years ago, the volume of the Colloquium materials in question, entitled A linguist of the XXI century (2002), as well the interviews volume under the name The Shell univers - Universul din scoică (2004)", notes the work editor Gheorghe Popa.

As the editorial rigors require a limited space, the material's selection and structuring considered the major objective of this book project, to include and reveal as much as possible, the dimensions of E. Coseriu's personality from various perspectives: biographical, spiritual, intellectual, professional, epistemic, etc. Thus, in the spring of this year, in accordance with the highest quality standards in hardcover edition, totaling 484 pages, this work sees the light of day, under the title Eugeniu Coșeriu - Vocația univeraslitătii / The Vocation of Universality. The book is structured in four chapters, distinct in presentation, but interdependent and complementary in content; it includes the protagonist's life both in a brief chronological formula mounted right at the beginning of the volume, and on thematic sections in the field of linguistics, literature, interviews - dialogues with and about Eugenio Coseriu, evocations - confessions and reconstructions, reflections on the great coserian model, and, of course, at the end, the iconographic compartment that makes accessible the life in images of master Coseriu. 
The information was distributed in each chapter, considering, mainly the chronological principle, of their elaboration period, and not from their publication date, because certain ideas or statements can be interpreted unambiguously only if they are related to political, historical, scientific, cultural climate", states the editor Gheorghe Popa, in the note edition of this project book.

Beyond the texts, with epistemological and documentary value, the volume ferments of emotion; most of the collaborators of this book project knew the Man Coseriu personally, which makes objectivism and subjectivism join hands in a great story.

\section{Coșeriu's peripatetics \\ - breif biographical data}

Eugenio Coseriu was born on July 27, 1921, in Mihaileni, Balti, Republic of Modova. After graduating from Ion Creanga High School in Balti, he enrolled at the University of Iasi (1939-1940), after which he received a scholarship, granted by the Italian State, at the Sapienza University in Rome (1941-1945), where he studied foreign languages, taking his doctorate in Slavic and Romanic philology. He then continued his studies in the field of philosophy at the Universities of Padua (1945) and Milan (1946-1949), defending a second doctorate in aesthetics.

In 1950, he left for Uruguay, at the University of Montevideo, where he founded his first department of linguistics and began to publish his basic studies. In 1963 he returned to Europe, being invited by the University of Tübingen, Germany, where he worked until the end of his life in 2002.

\section{- vocation of universality}

Coseriu incorporated in the history of this discipline the previous reflection on language. A profound connoisseur of classical languages and philosophy, The History of Linguistic Thought begins, in his vision, with Plato and Aristotle, passing through St. Augustine and St. Thomas, through Leibniz, W. von Humboldt and G. Vico, to reach Heidegger and Croce.

Based on these fundamental truths and Eugenio Coseriu's desire to assert himself, not „in a specific field of culture, but in a universal field”, we only related what was revealed to him, that the universal can be discovered even in a shell or a drop of water'as we find them evoked in the volume that is the subject of our review.

The coserian heritage will last over time; and this is due both to his genius and to the considerable and constant efforts of those who knew him, esteemed him, loved him, to commemorate him everywhere, on all continents of the world, through prestigious studies and publications. The idea more and more insistently circulated about E. Coseriu as a universal man, not in the Renaissance sense, but, in the sense of placing the field of 
research in a universal perspective and in close connection with all fields of knowledge" as the master himself confesses.

In conclusion, influenced by the thinking of Mircea Eliade, we can say with all conviction that Eugenio Coseriu entered the sacred time of mankind.

\section{Bibliography}

1. POPA, Gheorghe. Eugeniu Coșeriu - Vocația universalității. Chișinău, Editura Știința, 2021

\section{Sitography}

1. Editura Știința. Personalități notorii, [online] Disponibil http://editurastiinta. $\mathrm{md} /$ personalitati-notorii, accesed on August, 31, 2021

2. Editura Știința. Eugeniu Coșeriu - Vocația universalității, [online]

Disponibil http://editurastiinta.md/eugeniu-coseriu-vocatia-universalitatii, accesed on August, 31, 2021

3. Lingvistică coșeriană - origine și actualitate, [online] Disponibil https:// coseriu100.info/ro/coseriu100-ro/, accesed on August, 31, 2021 Observatorul Cultural - Centenarul Eugeniu Coșeriu, [online] Disponibil https://www.observatorulcultural.ro/ articol/centenarul-eugeniu-coseriu/, accesed on August, 31, 2021.

4. Omul și Limbajul. Centenar - Eugeniu Coșeriu, [online] Disponibil https:// mnlr.ro/omul-si-limbajul-centenar-eugen-coseriu/, accesed on September, 1, 2021. 